\title{
Cloning and Sequencing of a Gene from Bacillus amyloliquefaciens that Complements Mutations of the Sporulation Gene spoIID in Bacillus subtilis
}

\author{
By SHEILA M. TURNER AND JOEL MANDELSTAM* \\ Microbiology Unit, Department of Biochemistry, University of Oxford, South Parks Road, \\ Oxford OXI $3 Q U, U K$
}

(Received 26 March 1986; revised 16 June 1986)

A segment of DNA from Bacillus amyloliquefaciens, which complemented a mutant sporulation gene, spoIID68, in Bacillus subtilis, was cloned into a derivative of the temperate bacteriophage $\phi 105$. The segment of DNA included an entire structural gene and complemented the mutation spoIID298, in addition to spoIID68, in $B$. subtilis.

The nucleotide sequence of the gene from $B$. amyloliquefaciens was determined and compared with that of the $B$. subtilis gene; $74 \%$ homology was found in the coding region. Amino acid primary sequences derived from the nucleotide sequences of the two genes were also compared. The gene from $B$. amyloliquefaciens coded for a protein of 344 amino acid residues, one more than the protein coded by the corresponding gene from $B$. subtilis. Comparison of the primary amino acid sequences of the two genes showed that $78 \%$ of the residues were completely conserved and $8 \%$ were semi-conserved. Variation, however, was not random, i.e. some segments were much more highly conserved than others. Both proteins had a hydrophobic region at the $\mathrm{N}$-terminus.

\section{INTRODUCTION}

The degree of homology of the DNA from different species of Bacillus has previously been studied by both interspecific transformation and DNA hybridization (Seki et al., 1975, 1979). Interspecific transformation, however, is known to be extremely inefficient (te Riele \& Venema, $1982 a$ ). There is evidence that some genes - such as those conferring resistance to some antibiotics, those coding for the ribosomal proteins, RNAs and tRNAs, and those for cell division - are highly conserved (Dubnau et al., 1965a, b; Seki et al., 1975, 1979). Interspecific transformation of sporulation genes $s p o 0 A, s p o O B, s p o O F$ and $s p o O H$ with $B$. amyloliquefaciens $\mathrm{H}$ strain as donor and $B$. subtilis as recipient has been reported by Hoch \& Mathews (1973), although similar attempts with $B$. pumilus as donor were unsuccessful. Neither $B$. amyloliquefaciens nor $B$. pumilus were able to transform auxotrophic mutants of $B$. subtilis to prototrophy (Hoch \& Mathews, 1973). It was inferred from these results that sporulation genes were more closely conserved than auxotrophic genes. It has been proposed that differences in sequence homology are major barriers to interspecific transformation (Harris-Warrick \& Lederberg, 1978), though base pairing in complexes between heterologous DNA molecules has been observed (te Riele \& Venema, 1982 $a, b, 1984$ ).

Cloning of genes in $B$. subtilis has proved a more useful method than transformation for studying the homology of genes within the genus Bacillus. Genes from various species of the genus Bacillus have been cloned into $B$. subtilis and found to be functional, for example leuA and $i l v C$ from $B$. amyloliquefaciens (Yoshimura et al., 1983), neutral protease genes from $B$. amyloliquefaciens (Honjo et al., 1984) and B. stearothermophilus (Fujii et al., 1983), his $H$ from $B$. licheniformis (Weinrauch \& Dubnau, 1983), and $\alpha$-amylase genes from $B$. amyloliquefaciens (Palva, 1982; Lehtovaara et al., 1984) and B. licheniformis (Joyet et al., 1984). 
Sporulation genes cloned from species other than $B$. subtilis have also been found to function in $B$. subtilis, e.g. spoOH from B. licheniformis (Dubnau et al., 1981) and the spore coat C protein gene from $B$. megaterium (Goldrick \& Setlow, 1983). There is also evidence, from studies using monoclonal antibodies, that sporulating cultures of species other than $B$. subtilis recognize proteins similar to the sporulation-induced sigma factor $\sigma^{29}$ of $B$. subtilis (Trempy \& Haldenwang, 1985), which is the product of the sporulation gene spoIIG (Trempy et al., 1985).

The purpose of the present study was to clone sporulation genes from several species of Bacillus, to test them for complementation of mutated genes in B. subtilis, and to compare the degree of conservation of corresponding genes. This paper describes the construction of genomic libraries from seven species: $B$. amyloliquefaciens, $B$. cereus, $B$. thuringiensis, $B$. megaterium, $B$. polymyxa, $B$. natto and $B$. globigii. Complementation for a dozen out of a possible fifty or so known sporulation loci (Young \& Mandelstam, 1979) was tested. The cloning vector used for construction of the gene libraries, $\phi 105 \mathrm{~J} 9$ (Errington, 1984), has also been used to clone sporulation genes spoIID (Lopez-Diaz et al., 1986) and gerE (James \& Mandelstam, 1985) from B. subtilis.

The degree of conservation between the B. amyloliquefaciens and B. subtilis spoIID genes was studied by restriction analysis and by DNA sequencing. The gene from $B$. subtilis is a monocistronic operon, approximately $1.2 \mathrm{~kb}$ in length, coding for a protein of 343 amino acid residues with a strongly hydrophobic $\mathrm{N}$-terminal region (Lopez-Diaz et al., 1986). The present paper shows that the corresponding gene from $B$. amyloliquefaciens is very similar.

\section{METHODS}

Bacterial strains, phages and plasmids. These are listed in Table 1.

Bacillus strains were routinely maintained on nutrient agar (Oxoid). All Spo ${ }^{+}$strains sporulated readily on this medium. B. amyloliquefaciens, however, did not sporulate on this medium or on any of the other media tested, e.g. Schaeffer's agar (Schaeffer et al., 1965), soil extract agar (Fred \& Waksman, 1928), lactate-glutamate minimal agar (LGMA) or resuspension medium (Sterlini \& Mandelstam, 1969). Bacillus strains were tested for prototrophy by streaking onto LGMA plates incubated both at $30^{\circ} \mathrm{C}$ and at $37^{\circ} \mathrm{C}$. All the species of Bacillus listed in Table 1 grew prototrophically on LGMA. B. globigii and B. thuringiensis grew more readily on this medium at $30^{\circ} \mathrm{C}$ than at $37^{\circ} \mathrm{C}$. All cultures grew well on nutrient agar at $37^{\circ} \mathrm{C}$, and all except $B$. amyloliquefaciens produced spores.

Buffers. Ligation buffer was $50 \mathrm{mM}-\mathrm{Tris} / \mathrm{HCl} \mathrm{pH} \mathrm{7.4,} 10 \mathrm{~mm}-\mathrm{MgCl}_{2}, 10 \mathrm{~mm}$-DTT, $1 \mathrm{~mm}$-spermidine, $1 \mathrm{~mm}$ - ATP, $0.1 \mathrm{mg}$ bovine serum albumin (BSA) $\mathrm{ml}^{-1}$. TE buffer was $10 \mathrm{~mm}$-Tris/ $\mathrm{HCl}, 1 \mathrm{~mm}$-EDTA. Klenow reaction buffer (final concentration) was $10 \mathrm{~mm}$-Tris $\mathrm{pH} 8 \cdot 0,5 \mathrm{mM}-\mathrm{MgCl}_{2}$. TBE buffer was $90 \mathrm{~mm}$-Tris/ $\mathrm{HCl} \mathrm{pH} 8 \cdot 3,90 \mathrm{~mm}$-boric acid, $2.5 \mathrm{~mm}$-EDTA. Agarose gel loading buffer was $10 \mathrm{~mm}-\mathrm{Tris} / \mathrm{HCl} \mathrm{pH} \mathrm{7.4,} 1 \mathrm{~mm}-\mathrm{EDTA}, 20 \%$ (w/v) Ficoll, $0.05 \%$ bromophenol blue.

Restriction endonuclease digestions. Restriction enzymes were obtained from Amersham or BRL and used as recommended by the suppliers.

Transformations. Recipient cells of $B$. subtilis MY2000.68 blocked at stage II were transformed as described by Jenkinson (1983) using B. subtilis 168 chromosomal DNA, B. amyloliquefaciens chromosomal DNA, plasmid pS1 DNA and phage $\phi 105 S 1$ DNA digested with $B c l$. The final concentration of transforming DNA used was approximately $1 \mu \mathrm{g} \mathrm{ml}^{-1}$. Transforming mixtures were spread onto Schaeffer's agar, and treated with chloroform after $18 \mathrm{~h}$ incubation at $37^{\circ} \mathrm{C}$. Spo ${ }^{+}$colonies were identified by the brown colour associated with spore production. The colonies were checked microscopically for the presence of spores.

Preparation of DNA. Chromosomal DNA from B. amyloliquefaciens was prepared by the method of Marmur (1961). Plasmid DNA was extracted from E. coli by the alkaline lysis method (Maniatis et al., 1982). Phage DNA (M13, $\phi 105 \mathrm{~J} 9$ and recombinants of both) was prepared as described in the Amersham booklet M13 Cloning and Sequencing Handbook.

Construction of genomic libraries. Chromosomal DNA from various species of bacilli (B. amyloliquefaciens, $B$. cereus, B. thuringiensis, B. megaterium, B. polymyxa, B. natto and B. globigii) was digested with $B c l$ I. The phage vector $\phi 105 \mathrm{~J} 9$ (Errington, 1984) was cleaved at a unique site in the polylinker with BamHI, and the chromosomal DNA ( $250 \mathrm{ng}$ ) fragments were ligated into the vector $(500 \mathrm{ng})$. The resulting recombinant phage preparation was used to transfect protoplasts of CU267 and the resulting pool of recombinant phages was harvested as described by Errington (1984).

Complementation of asporogenous B. subtilis mutants. Portions $(300 \mu \mathrm{l})$ of $5 \mathrm{ml}$ cultures of $B$. subtilis sporulation mutants grown in brain heart infusion broth (BHIB) were infected with $200 \mu$ l of the mixed pool of recombinant phages while still in exponential phase. Each $500 \mu \mathrm{l}$ of the mixture of cells and phage was then spread on Schaeffer's agar and Spo+ colonies were selected as described above. The colonies were checked microscopically 
Table 1. Bacterial strains, phages and plasmids

Strain

Genotype or description

Source or reference

B. subtilis

MY2000.68

298.2

CU267

168

B. amyloliquefaciens

B. cereus

B. thuringiensis

B. megaterium K.M.

B. polymyxa

B. natto

B. globigii

E. coli

JM103

JM107

Bacteriophages

$\phi 105 \mathrm{~J} 9$

$\phi 105 \mathrm{LD} 2$

$\phi 105 S 1$

M13mp10, 11

Plasmids

pUC18

pS1

$\mathrm{pS} 2$

pS3
spoIID68 lys-1 pyrDI

spoIID298 phe-12

trpC2 ilvB2 leuB16

$\operatorname{trpC2} ; \mathrm{Spo}^{+}$

Prototrophic; $\mathrm{Spo}^{-*}$

Prototrophic; $\mathrm{Spo}^{+}$

$\Delta$ (lac-pro) thi strA supE end A sbcB15 hsdR4

$\mathrm{F}^{\prime}$ traD36 proAB lacI ${ }^{\mathrm{q}} \mathrm{Z} \Delta \mathrm{M} 15$

$\triangle$ (lac-pro) endAl gyrA96 thi-1 hsdRI7 supE44

relAI $\mathrm{F}^{\prime}$ traD36 proAB ${ }^{+}$lacI $^{\mathrm{q}} \mathrm{Z} \Delta \mathrm{M} 15$

Cloning vector

spoIID ${ }^{+}$(B. subtilis), $2 \mathrm{~kb} \mathrm{Mbol} \mathrm{insertion} \mathrm{in}$ $\phi 105 \mathrm{~J} 9$

spoIID ${ }^{+}$(B. amyloliquefaciens), $3.8 \mathrm{~kb} \mathrm{BclI}$

insertion in $\phi 105 \mathrm{~J} 9$

Sequencing vector

M. Yudkin, Oxford Univ., UK

Laboratory stock

S. A. Zahler, Cornell Univ., NY, USA

Laboratory stock

\}

Torrey strain 10785

Laboratory strain

K. McQuillen, Cambridge Univ. UK

Laboratory strain

ATCC 15245

NCIB 8058

Messing et al. (1981)

Yanisch-Perron et al. (1985)

Errington (1984)

Lopez-Diaz et al. (1986)

This paper

Messing (1983)

Amp $^{\mathrm{R}}$

pUC18 $+3.8 \mathrm{~kb}$ insert from $\phi 105 \mathrm{~S} 1$

pUC18 + $1.6 \mathrm{~kb}$ EcoRI fragment of pS1

pUC18 + $0.4 \mathrm{~kb}$ EcoRI fragment of $\mathrm{pSl}$

Norrander et al. (1983)

This paper

* Unable to cultivate spores under conditions provided (see Methods).

for the presence of spores. The auxotrophic requirements of the recipient cells for lysine and uracil were checked using lactate-glutamate minimal agar supplemented with the appropriate nutritional requirements. Sporulating colonies were tested for the presence of transducing phage as described below.

Preparation and testing of phage lysates. Small scale lysates were made from $5 \mathrm{ml}$ bacterial cultures in BHIB. Cultures were grown with shaking at $37^{\circ} \mathrm{C}$ to a density of $0.085 \mathrm{mg}$ dry wt bacteria $\mathrm{ml}^{-1}, 12 \mu \mathrm{l}$ mitomycin $\mathrm{C}$ (Sigma; $200 \mu \mathrm{g} \mathrm{ml}^{-1}$ ) was added and the cultures were incubated for a further $25 \mathrm{~min}$. Each culture was centrifuged and the cells were resuspended in $5 \mathrm{ml}$ of fresh warm BHIB and incubated for 2-3h, until they had lysed. Cells and debris were pelleted by centrifugation and the supernatant was sterilized by passage through a $0.45 \mu \mathrm{m}$ Millipore filter. The phage lysate thus obtained was stored at $4{ }^{\circ} \mathrm{C}$.

Large scale lysates were prepared in the same manner from $200 \mathrm{ml}$ culture, using $0.5 \mathrm{ml}$ mitomycin C $(200 \mu \mathrm{g}$ $\mathrm{ml}^{-1}$ ) to induce the prophage. Phage was then purified as described by Jenkinson \& Mandelstam (1983).

Lysates were tested for transducing ability by spotting $10 \mu \mathrm{l}$ drops on lawns of recipient cells growing on Schaeffer's agar. Where the phage conferred the ability to sporulate on recipient cells a patch of $\mathrm{Spo}^{+}$cells could be observed amidst a lawn of $\mathrm{Spo}^{-}$cells.

$D N A$ hybridization. Plasmid pUC18, with the entire $3.8 \mathrm{~kb}$ chromosomal DNA fragment from $B$. amyloliquefaciens inserted into its polylinker (see Resuits), was digested with $H i n \mathrm{dIII}$ and $E c o$ RI. The digests were run on agarose gels and transferred to nitrocellulose (Anderman, East Molesey, Surrey, UK) by the method of Southern (1975).

The radioactive probe used for hybridization consisted of $\phi 105 \mathrm{~J} 9$ with a $1.6 \mathrm{~kb}$ EcoRI-SalI insert of $B$. subtilis DNA, comprising the spoIID locus, designated $\phi 105 \mathrm{LD} 2$ (Lopez-Diaz et al., 1986). The probe was nick-translated and labelled with ${ }^{32} \mathrm{P}$ (Amersham kit). Filter preparation and autoradiography were as described by Maniatis $e t$ al. (1982). 
DNA electrophoresis. Digested DNA was mixed with loading buffer, heated at $65^{\circ} \mathrm{C}$ for $10 \mathrm{~min}$, separated on $0.7 \%$ agarose gels (Sigma type II) in TBE buffer and visualized by ethidium bromide fluorescence.

To remove a particular fragment for ligation, the band was cut out of a low melting point $(0.6 \%$, w/v) agarose gel (BRL). The agarose was melted by heating at $65^{\circ} \mathrm{C}$ for $5 \mathrm{~min}$ with an equal volume of TE buffer. The DNA was extracted with phenol, and precipitated overnight at $-20^{\circ} \mathrm{C}$ in 2 vols ethanol and $0.1 \mathrm{vol} .2 .5 \mathrm{M}$-ammonium acetate. The DNA was collected by centrifugation in a Beckman microfuge for $10 \mathrm{~min}$ at $4{ }^{\circ} \mathrm{C}$, washed once in $80 \%(v / v)$ ethanol, vacuum dried and resuspended in TE buffer.

DNA sequencing. Fragments of DNA from plasmid pS2 and pS3 were sequenced by the dideoxy chain termination method of Sanger et al. (1977). All procedures, including cloning in M13 phage, selection of recombinants in E. coli JM103 and JM107, the sequencing reaction, and the running of buffer gradient gels, were done as described in the Amersham booklet M13 Cloning and Sequencing Handbook.

Subcloning fragments of chromosomal DNA. The original $3.8 \mathrm{~kb}$ fragment of chromosomal DNA was removed from the polylinker of $\phi 105 \mathrm{~J} 9$ with $X b a \mathrm{I}$ and Pst I. A sample of the fragment (100 $\mathrm{ng}$ ) was then ligated into the corresponding unique restriction sites in the polylinker of pUC18 $(20 \mathrm{ng})$, and the plasmid was transformed into $E$. coli JM103 as described by Amersham in the M13 Cloning and Sequencing Handbook.

Comparison of DNA sequences. Comparison of DNA sequences from $B$. subtilis and $B$. amyloliquefaciens was done by eye.

Comparison of amino acid sequences. This was done by eye and by using the computer program HYDROPLOT described by Kyte \& Doolittle (1982) and modified by R. Staden (personal communication).

\section{RESULTS AND DISCUSSION}

\section{Genomic libraries}

When genomic libraries constructed from seven species of Bacillus ( $B$. amyloliquefaciens, $B$. cereus, $B$. thuringiensis, $B$. megaterium, B. polymyxa, B. natto and B. globigii) were tested for their ability to complement a variety of sporulation genes (spoIIAA, spoIIAC, spoIIB, spoIIC, spoIID, spoIIE, spoIIG, spoIIIA, spoIIIB, spoIVA, spoIVC, spoIVF, spoVA) in $B$. subtilis, only one positive result was obtained. The library made using $B$. amyloliquefaciens chromosomal DNA contained a recombinant phage able to complement a defective spoIID gene in $B$. subtilis.

$B$. amyloliquefaciens is taxonomically one of the most similar species to $B$. subtilis (Gibson \& Gordon, 1974; Seki et al., 1978). It is worth noting that although the library of the strain of $B$. amyloliquefaciens used gave a positive result, the strain did not sporulate under any of the conditions used.

\section{Isolation of recombinant phage $\phi 105 S 1$}

Competent cells of $B$. subtilis MY2000.68 spoIID68 were transformed with chromosomal DNA from B. amyloliquefaciens; no $\mathrm{Spo}^{+}$colonies were observed. The same $B$. subtilis mutant was infected with the pool of recombinant phages made using $\phi 105 \mathrm{~J} 9$; approximately $50 \mathrm{Spo}^{+}$ colonies per $\mathrm{ml}$ of infected culture were observed. In these colonies, where the mutant gene had been complemented by the phage, spores were produced at the same incidence as in wild-type $\mathrm{Spo}^{+}$strains.

Eight of the $\mathrm{Spo}^{+}$colonies were sub-cultured on nutrient agar. All eight cultures retained their $\mathrm{Spo}^{+}$phenotype on repeated sub-culture. The auxotrophic markers of these isolates were checked and all the isolates were found to require both uracil and lysine, as expected. Each of the small scale lysates prepared from these isolates gave rise to a transducing lysate able to confer the ability to sporulate on further cultures of MY2000.68. Lysates were checked, before testing, to see that there was no bacterial contamination.

A single colony was selected from the first sub-culture of one of the eight isolates. This strain was used for all subsequent work. The transducing lysate obtained from this culture not only complemented spoIID68 but also complemented spoIID298 (Lopez-Diaz et al.,1986). The phage was designated $\phi 105 \mathrm{~S} 1$.

\section{Hybridization and restriction analysis}

A preliminary restriction map of the insert in phage $\phi 105 \mathrm{~S} 1$ was constructed, and it was found that there were no sites for PstI or XbaI other than those in the polylinker. The insert was removed with these two enzymes and subcloned into the corresponding unique sites in the 


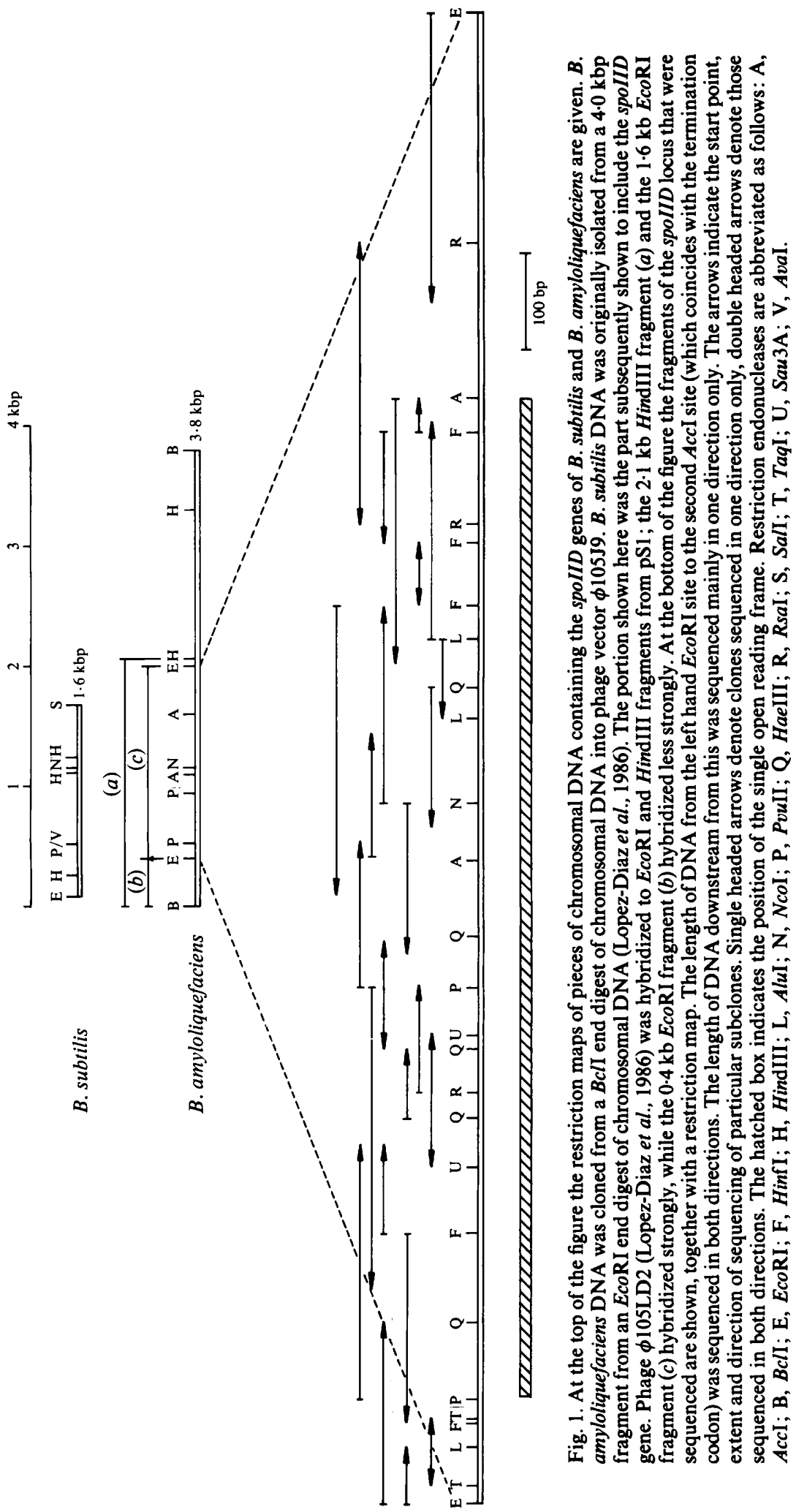




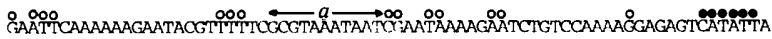

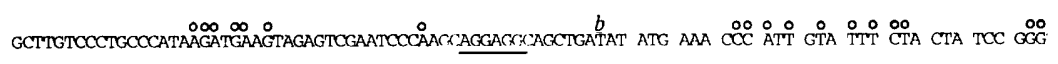

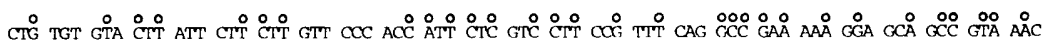
여

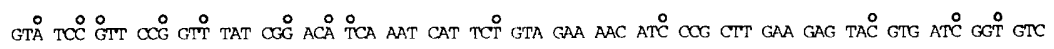

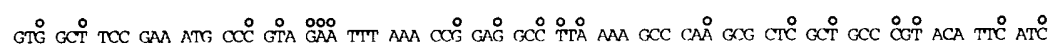
GTC AGA CTG ATG GTT '̊

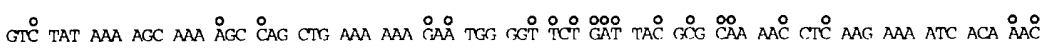

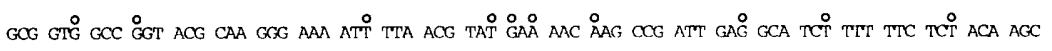

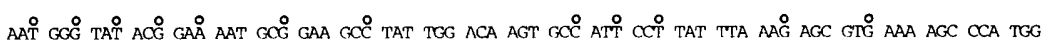

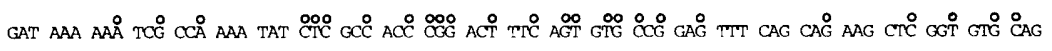

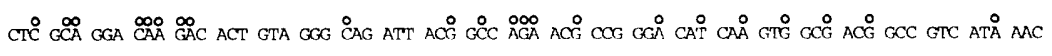

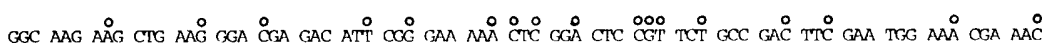

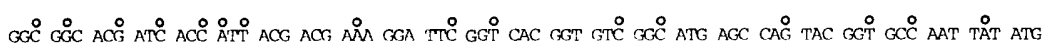

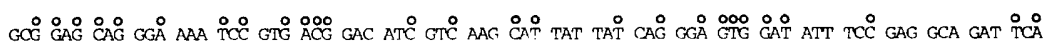

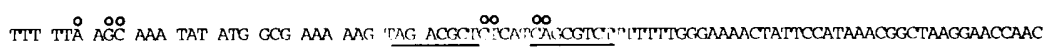
GGACTCATATAACGAAAGGCTAAAGGCTISACAAATGOCGGATAGATAGAT:COCACOGGTGNAATCACTTATAAAAATGCCCCTTCTATGTGAAATGT ACGCAAAATAATGAGGAACCCCGTCCTAATTTATT'TCCCTTTTCAACTCATTTACCATAAA

Fig. 2. Nucleotide sequence of the $B$. amyloliquefaciens spoIID gene. The sequence shown is from the left hand $E c o$ RI site shown in Fig. 1 to about 200 bp after the right hand $A c c$ I site. $a, b$ and $c$ show base pairs additional to those found in $B$. subtilis. The putative terminator and ribosome binding sites are underlined., Region with homology to the known promoter sequence for the -10 region recognized by $\sigma^{29}$ RNA polymerase in $B$. subtilis (Johnson et al., 1983); $O$, bases differing from those found in corresponding positions in $B$. subtilis (sequences downstream from the termination codon have not been compared in this way as they are so dissimilar).

polylinker of plasmid pUC18. A more detailed restriction map of the new plasmid, pS1, was then prepared (Fig. 1) and it revealed that the insert was $3.8 \mathrm{~kb}$ long.

It was assumed that the spoIID gene of $B$. amyloliquefaciens would be similar in size to the corresponding gene in $B$. subtilis (about $1.2 \mathrm{~kb}$ ), and perhaps have the same restriction map; however, a comparison of the restriction maps of the DNA from $B$. amyloliquefaciens and $B$. subtilis revealed no obvious relationship (Fig. 1). The $B$. amyloliquefaciens DNA had some restriction sites in common with the $B$. subtilis gene, e.g. HindIII, PvuII and NcoI, but their relative positions were different. The $B$. amyloliquefaciens DNA also lacked some of the restriction sites of the $B$. subtilis gene, e.g. AvaI and SalI.

It was hoped that hybridization of a radioactively labelled probe consisting of the $B$. subtilis spoIID gene to the $B$. amyloliquefaciens DNA would reveal a section of homologous DNA. Plasmid pSI was digested with HindIII and EcoRI, blotted to nitrocellulose as described by Southern (1975) and hybridized to $\phi 105$ LD2 (Lopez-Diaz et al., 1986) labelled with ${ }^{32} \mathrm{P}$. The probe hybridized strongly to a $1.6 \mathrm{~kb} E c o$ RI fragment and to a $2.1 \mathrm{~kb} H$ indIII fragment of the insert, and less strongly to a $0 \cdot 4 \mathrm{~kb} E c o \mathrm{RI}$ fragment (Fig. 1). It was known that the coding region 
of the spoIID gene of $B$. subtilis was approximately $1.0 \mathrm{~kb}$ in length so it was possible that the gene from $B$. amyloliquefaciens could be entirely contained within the $1.6 \mathrm{~kb} E c o \mathrm{RI}$ fragment (Fig. 1). This fragment was subcloned into pUC18 as a preliminary step to DNA sequencing. The plasmid was designated pS2. The $0.4 \mathrm{~kb} E c o \mathrm{RI}$ fragment was also cloned into pUC18, and the plasmid was designated pS3.

\section{DNA sequencing}

The nucleotide sequence of the $B$. amyloliquefaciens spoIID gene, determined using the dideoxy chain termination method of Sanger et al. (1977), is shown in Fig. 2. As expected, the whole of the gene lay entirely within the $1.6 \mathrm{kbp} E c o$ RI fragment contained in pS2. The fragments sequenced are shown in Fig. 1. The structural gene and short stretches on either side were sequenced in both directions. A further portion downstream from the termination codon was sequenced in one direction only, as was a portion of the DNA upstream of the first EcoRI site. Because our main interest was in the portion of DNA containing the coding region, we made no further effort to determine either the upstream or the downstream sequence with complete accuracy. The degree of homology decreased as distance from the coding region increased. The homology found in the $0.4 \mathrm{~kb} E c o \mathrm{RI}$ upstream fragment would account for the observed hybridization to $\phi 105 \mathrm{LD} 2$.

The DNA sequence of the $B$. amyloliquefaciens gene was compared with the sequence from the $B$. subtilis gene. It was possible to align the two sequences and to identify the initiation codon, the coding region of the gene, the termination codon, the probable ribosome binding site and the $\sigma^{29}$ recognition site (see Fig. 2). Only one large open reading frame was found, as in $B$. subtilis. The protein encoded by the gene is almost exactly the same size in both species, 343 amino acid residues in $B$. subtilis and 344 in B. amyloliquefaciens.

As the $B$. amyloliquefaciens gene was fully functional in $B$. subtilis it was apparent that the 'foreign' gene was able to use the transcriptional and translational machinery of the $B$. subtilis host cell. This is not surprising in view of the strong similarity between the two genes.

Cases in which promoters from other organisms function in $B$. subtilis are well documented: e.g., the promoters of the subtilisin gene (Wells et al., 1983) and the $\alpha$-amylase gene (Palva, 1982) from $B$. amyloliquefaciens, the penicillinase gene (Gray \& Chang, 1981) and a thermostable $\alpha-$ amylase gene (Ortlepp et al., 1983) from $B$. licheniformis, and the $\beta$-lactamase I gene from $B$. cereus (Wang et al., 1985).

The nucleotide sequence of the region of DNA upstream of the codon initiating translation is highly conserved between the two species, although $B$. amyloliquefaciens has an insertion of 11 base pairs at one position ( $a$, Fig. 2) and of a further base pair ( $b$, Fig. 2 ) just before the initiation of translation. In the protein-coding region, B. amyloliquefaciens has an extra triplet (c, Fig. 2), which codes for the extra amino acid already mentioned. There is an $84 \%$ homology between the two nucleotide sequences in the region between nucleotide 1 and the initiation of translation codon (Fig. 2).

The six base pair sequence, CATATT, located 60 nucleotides before the start of translation shows homology to the -10 region recognized by $\sigma^{29}$ (Johnson et al., 1983). Lopez-Diaz et al. (1986) found exactly the same sequence in the $B$. subtilis spoIID gene. The proposed ribosome binding site, AGGAGG (Shine \& Dalgarno 1974), was also the same in the B. amyloliquefaciens and $B$. subtilis spoIID genes. The additional base just before the initiation codon of the $B$. amyloliquefaciens spoIID gene means that there is a 10 nucleotide space between the Shine Dalgarno sequence and the initiation codon, rather than the nine found in the B. subtilis spoIID gene. Both species use the codon ATG for the initiation of translation. Overall homology between the coding regions of the genes from the two species is $74 \%$. As Fig. 2 shows, differences are not randomly distributed throughout the length of the DNA.

Since a change in just one nucleotide can create or destroy a restriction site, the observed differences in sequence have given rise to very dissimilar restriction maps, in spite of the high degree of homology of the genes (Fig. 1). 
B. amyloliquefaciens MKPIV FLLSG LCVLI LLVPT ILV눌 FOAEK GAAUN REPGH KTAHT IRETK GAEPT LKESP B. subtilis MKQFA ITLSV LCALI LLVPT LLVIP FOHNK EAGAS VESFK TAVST KPASK GAE T LKASP

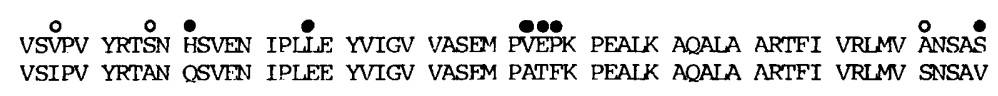

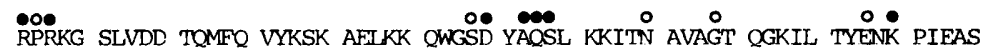
EAPKG SLVDD TQMFQ VYKSK AFIKK OWGTS YETKL KKITD AVAST QGKIL TYNNQ PIFAS

FFSTS NGYTE NAFAY WTSAI PYLKS VKSPW DKKSP KYIAT RTFSV PEFCQ KLGVQ LAGQD FFSTS NGYTE NAEAY WTSAI PYLKS VKSPW DKKSP KYKAT KTFTA AEFCQ KLGVK LDGSS

TVGQI TARTP GHOVA TAVIN GKKLK GRDIR EKIGL RSADF ETKRN GGTIT ITTIKG FGHGV AVGKI TGETP GHONA TAVIN GKTIK GRDIR EKISIL NSADF EWKRN GDTIT VTTRG FGHGV

$\circ$
GMSOY GANYM AEQGK SVIDI VKHYY QGVDI SEADS FLSKY MAKK
GMSQY GANFM AKEGK TVDDI VKYYY OGTQI SFADA FLNKY MAKK

Fig. 3. Comparison of the primary amino acid sequences deduced for the polypeptides coded for by the spoIID genes of $B$. subtilis (bottom line) and $B$. amyloliquefaciens (top line). $O$, Amino acid residues which have been semi-conserved between species; $\mathcal{O}$, amino acid residues not conserved according to the scheme proposed by Dayhoff et al. (1978) [groups of semi-conserved amino acid residues are as follows: (i) A, S, T, P, G; (ii) N, D, E, Q; (iii) H, R, K, (iv) M, L, I, V; (v) F, Y, W ; (vi) C]. The protein from $B$. amyloliquefaciens has one extra residue, the proline residue marked with an asterisk $\left({ }^{*}\right)$.

\section{Primary protein sequence}

The primary amino acid sequences of the two proteins were predicted from the nucleotide sequences. Although $B$. amyloliquefaciens has one extra amino acid - a proline residue at position 54 (Fig. 3) - 78\% of the amino acid residues have been completely conserved and, using the scheme proposed by Dayhoff et al. (1978), $8 \%$ have been semi-conserved and only $14 \%$ have changed completely.

A strongly hydrophobic region at the $\mathrm{N}$-terminus is characteristic of a signal peptide region of a presecretory protein (Perlman \& Halvorson, 1983). One such protein from B. amyloliquefaciens is the $\alpha$-amylase presecretory protein (Palva et al., 1981). As in B. subtilis, 19 of the first 26 amino acid residues of the spoIID protein are hydrophobic, although nine of these residues differ from those found in corresponding positions in $B$. subtilis. Relative hydrophobicity plots (HYDROPLOT) of the two proteins are shown in Fig. 4. This clearly shows the two strongly hydrophobic regions of the $\mathrm{N}$-terminal ends of the proteins; the rest of the plots are also strikingly similar.

Both proteins contain the positively charged amino acid lysine at position 2, although the $B$. amyloliquefaciens protein does not exhibit the proposed cleavage site Ala-Gly-Ala at positions 32-34 (Lopez-Diaz et al., 1986), or any other similar form of the common cleavage recognition site Ala-X-Ala (Perlman \& Halvorson, 1983). Amino acid residues 14-26 are almost completely conserved between the two species, there being only two semi-conservative changes in this stretch, leucine to isoleucine at position 21 , and isoleucine to leucine at position 24 . The ensuing stretch of 23 amino acids (positions 27-49) is not particularly similar in the two proteins, but the next stretch of approximately 70 amino acid residues (positions 50-119) is highly conserved. This reflects the non-random distribution of differences in the nucleotide sequence; although overall the amino acid sequence is $78 \%$ conserved, the variations that occur are unevenly distributed. There are clearly regions of high conservation and, conversely, regions where considerable drift has occurred.

Two of the mutations known to lie in the spoIID locus of B. subtilis, spo68 and spo298, have been mapped in this laboratory (Lopez-Diaz et al., 1986). Mutation spo298 is approximately 0.3 $\mathrm{kbp}$ from the start of translation and mutation spo68 is very close to the termination codon of the gene. The amino acid sequence in these regions is very similar in both species of bacilli. 


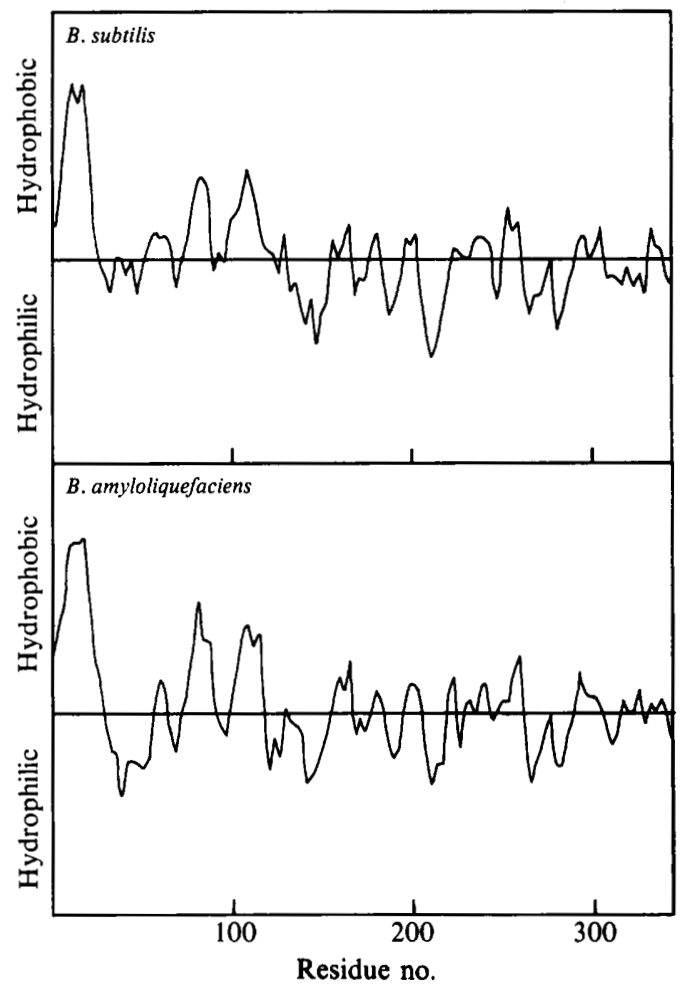

Fig. 4. Hydroplots of spoIID proteins from B. subtilis and B. amyloliquefaciens. Primary protein sequences were inferred from the nucleotide sequences. Hydrophobic areas are displayed above the central lines, hydrophilic areas below. Span length $=11$, output length $=3$.

The same termination codon, TAG, is found in both nucleotide sequences. In the $B$. subtilis sequence, a putative transcriptional termination stem and loop structure has been identified after the termination codon (Lopez-Diaz et al., 1986). A similar function is proposed for an analogous region in the $B$. amyloliquefaciens sequence (Fig. 2), although this proposed stem and loop structure is smaller by six base pairs than that for $B$. subtilis.

In conclusion it can be said that the genes from the two species are very similar both in respect of nucleotide sequence and inferred primary protein structure. Secondary protein structure and possible functions of the proteins are being investigated.

We would like to thank Dr J. Errington for advice and helpful discussions. This work was supported by grants from Elf Aquitaine (UK) and the Science and Engineering Research Council.

\section{REFERENCES}

Dayhoff, M. O., Schwartz, R. M. \& ORCUTt, B. C. (1978). A model of evolutionary change in proteins. In Atlas of Protein Sequence and Structure, vol. 5, supplement 3, pp. 345-352. Edited by M. O. Dayhoff. Washington, DC: National Biomedical Research Foundation.

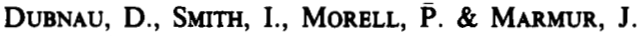
$(1965 a)$. Gene conservation in Bacillus species. I. Conserved genetic and nucleic acid base sequence homologies. Proceedings of the National Academy of Sciences of the United States of America 54, 491498.
Dubnau, D., Smith, I. \& Marmur, J. (1965b). Gene conservation in Bacillus species. II. The location of genes concerned with the synthesis of ribosomal components and soluble RNA. Proceedings of the National Academy of Sciences of the United States of America 54, 724-730.

Dubnau, E., Ramakrishna, N., Cabane, K. \& Smith, I. (1981). Cloning of an early sporulation gene in Bacillus subtilis. Journal of Bacteriology 147, 622-632.

ERRINGTON, J. (1984). Efficient Bacillus subtilis cloning system using bacteriophage vector $\phi 105 \mathrm{~J} 9$. Journal of General Microbiology 130, 2615-2628. 
Fred, E. B. \& Waksman, S. A. (1928). Laboratory Manual of General Microbiology. New York: McGraw Hill Book Company.

Fuji, M., Takagi, M., Imanaka, T. \& Aiba, S. (1983). Molecular cloning of a thermostable neutral protease gene from Bacillus stearothermophilus in a vectorplasmid and its expression in Bacillus stearothermophilus and Bacillus subtilis. Journal of Bacteriology 154, 831-837.

Gibson, T. \& Gordon, R. E. (1974). Genus I. Bacillus Cohn. 1872, 174. In Bergey's Manual of Determinative Bacteriology, 8th edn, pp. 529-550. Baltimore: Williams \& Wilkins.

GoldRICK, S. \& Setlow, P. (1983). Expression of a Bacillus megaterium sporulation-specific gene during sporulation of Bacillus subtilis. Journal of Bacteriology 155, 1459-1462.

Gray, O. \& Chang, S. (1981). Molecular cloning and expression of Bacillus licheniformis $\beta$-lactamase gene in Escherichia coli and Bacillus subtilis. Journal of Bacteriology 145, 422-428.

HARRIS-WARrick, R. M. \& Lederberg, J. (1978). Interspecies transformation in Bacillus: sequence heterology as the major barrier. Journal of Bacterio$\log y 133,1237-1245$.

Hoch, J. A. \& Mathews, J. (1973). Chromosomal location of pleiotrophic negative sporulation mutations in Bacillus subtilis. Genetics 73, 215-228.

Honjo, M., Manabe, K., Shimada, H., Mita, I., NaKayama, A. \& Furutani, Y. (1984). Cloning and expression of the gene for neutral protease of Bacillus amyloliquefaciens in Bacillus subtilis. Journal of Biotechnology 1, 265-277.

James, W. \& Mandelstam, J. (1985). Protease production during sporulation of germination mutants of Bacillus subtilis and the cloning of a functional gerE gene. Journal of General Microbiology 131, 24212430 .

JENKINSON, H. F. (1983). Altered arrangement of proteins in the spore coat of a germination mutant of Bacillus subtilis. Journal of General Microbiology 129, 1945-1958.

Jenkinson, H. F. \& Mandelstam, J. (1983). Cloning of the Bacillus subtilis lys and spoIIIB genes in phage $\phi 105$. Journal of General Microbiology 129, 22292240.

Johnson, W. C., Moran, C. P., JR \& Losick, R. (1983). Two RNA polymerase sigma factors from Bacillus subtilis discriminate between overlapping promoters for a developmentally regulated gene. Nature, London 302, 800-804.

Joyet, P., Guerineau, M. \& Heslot, H. (1984). Cloning of a thermostable $\alpha$-amylase gene from Bacillus licheniformis and its expression in Escherichia coli and Bacillus subtilis. FEMS Microbiology Letters 21, 353-358.

KYTE, J. \& DoolitTLE, R. F. (1982). A simple method for displaying the hydropathic character of a protein. Journal of Molecular Biology 157, 105-132.

Lehtovaara, P., Ulmanen, I. \& Palva, I. (1984). In vivo transcription initiation and termination sites of an $\alpha$-amylase gene from Bacillus amyloliquefaciens cloned in Bacillus subtilis. Gene 30, 11-16.

lopez-Diaz, I., Clarke, S. \& Mandelstam, J. (1986). spoIID operon of Bacillus subtilis: cloning and sequence. Journal of General Microbiology 132, $341-$ 354.

Maniatis, T., Fritsch, E. F. \& SAmbrooK, J. (1982). Molecular Cloning: A Laboratory Manual. Cold Spring Harbor, NY: Cold Spring Harbor Laboratory.

MARMUR, J. (1961). A procedure for the isolation of deoxyribonucleic acid from micro-organisms. Journal of Molecular Biology 3, 208-218.

Messing, J. (1983). New M13 vectors for cloning. Methods in Enzymology 101, 20-78.

Messing, J., Crea, R. \& Seeburg, P. H. (1981). A system for shotgun DNA sequencing. Nucleic Acids Research 9, 309-321.

Norrander, J., Kempe, T. \& Messing, J. (1983). Improved M13 vectors using oligonucleotide-directed mutagenesis. Gene 26, 101-106.

Ortlepp, S. A., Ollington, J. F. \& McConnell, D. J. (1983). Molecular cloning in Bacillus subtilis of a Bacillus licheniformis gene encoding a thermostable $\alpha$-amylase. Gene 23, 267-276

Palva, I. (1982). Molecular cloning of the $\alpha$-amylase gene from Bacillus amyloliquefaciens and its expression in Bacillus subtilis. Gene 19, 81-87.

Palva, I., Pettersson, R. F., Kalkkinaen, N., LehtovaAra, P., Sarvas, M., SöDerlund, H., TAKKINEN, K. \& KäÄRIÄINEN, L. (1981). Nucleotide sequence of the promoter and $\mathrm{NH}_{2}$-terminal signal peptide region of the $\alpha$-amylase gene from Bacillus amyloliquefaciens. Gene 15, 43-51.

Perlman, D. \& Halvorson, H. O. (1983). A putative signal peptidase recognition site and sequence in eukaryotic and prokaryotic signal peptides. Journal of Molecular Biology 167, 391-409.

Te Riele, H. P. \& Venema, G. (1982a). Molecular fate of heterologous bacterial DNA in competent Bacillus subtilis. I. Processing of $B$. pumilus and B. licheniformis DNA in B. subtilis. Genetics 101, 179-188.

TE Riele, H. P. \& Venema, G. (1982b). Molecular fate of heterologous bacterial DNA in competent Bacillus subtilis. II. Unstable association of heterologous DNA with the recipient chromosome. Genetics 102, 329-340.

TE RIELE, H. P. \& VENEMA, G. (1984). Molecular fate of heterologous bacterial DNA in competent Bacillus subtilis: further characterization of unstable association between donor and recipient DNA and the involvement of the cellular membrane. Molecular and General Genetics 195, 200-208.

Sanger, F., Nicklen, S. \& Coulson, A. R. (1977). DNA sequencing with chain terminating inhibitors. Proceedings of the National Academy of Sciences of the United States of America 74, 5463-5467.

SChaEFfer, P., IONESCO, H., RYTER, A. \& BALASSA, G. (1965). La sporulation de Bacillus subtilis: étude génétique et physiologique. Colloques internationaux du Centre national de la recherche scientifique 124, $553-563$.

Seki, T., Oshima, T. \& Oshima, Y. (1975). Taxonomic study of Bacillus by deoxyribonucleic acid hybridisation and interspecific transformation. International Journal of Systematic Bacteriology 25, 258-270.

Seki, T., Chung, W. C., Mikani, H. \& Oshima, Y. (1978). Deoxyribonucleic acid homology and taxonomy of the genus Bacillus. International Journal of Systematic Bacteriology 28, 182-189. 
Seki, T., Tsunekawa, H., Nakamura, K., YoshiMURA, K. \& OSHIMA, Y. (1979). Conserved genes in Bacillus subtilis and related species. Journal of Fermentation Technology 57, 488-504.

Shine, J. \& Dalgarno, L. (1974). The 3'-terminal sequence of Escherichia coli $16 \mathrm{~S}$ ribosomal RNA: complementarity to nonsense triplets and ribosome binding sites. Proceedings of the National Academy of Sciences of the United States of America 71, 13421346.

Southern, E. M. (1975). Detection of specific sequences among DNA fragments separated by gel electrophoresis. Journal of Molecular Biology 98, 503-517.

Sterlini, J. M. \& Mandelstam, J. (1969). Commitment to sporulation in Bacillus subtilis and its relationship to development of actinomycin resistance. Biochemical Journal 113, 29-37.

Trempy, J. E. \& Haldenwang, W. G. (1985). $\sigma^{29}$-like protein is a common sporulation-specific element in bacteria of the genus Bacillus. Journal of Bacteriology 164, 1356-1358.

Trempy, J. E., Bonamy, C., Szulmajster, J. \& Haldenwang, W. G. (1985). Bacillus subtilis sigma factor $\sigma^{29}$ is the product of the sporulation-essential gene spoIIG. Proceedings of the National Academy of
Sciences of the United States of America 82, 41894192.

Wang, W., Mezes, P. S. F., Yang, Y. Q., BlacheR, R. W. \& LAMPEN, J. O. (1985). Cloning and sequencing of the $\beta$-lactamase I gene of Bacillus cereus $5 / B$ and its expression in Bacillus subtilis. Journal of Bacteriology 163, 487-492.

WeinRauch, Y. \& DubnaU, D. (1983). Plasmid marker rescue transformation in Bacillus subtilis. Journal of Bacteriology 154, 1077-1087.

Wells, J. A., Ferrari, E., Henner, D. J., Estell, D. A. \& CHEN, E. Y. (1983). Cloning, sequencing and secretion of Bacillus amyloliquefaciens subtilisin in Bacillus subtilis. Nucleic Acids Research 11, 79117925.

Yanisch-Perron, C., Vieira, J. \& Messing, J. (1985). Improved M13 phage cloning vectors and host strains: nucleotide sequences of the M13mpl8 and pUC19 vectors. Gene 33, 103-119.

Yoshimura, K., Ikenaka, Y., Mural, M., Tanabe, M., SEKI, T. \& OshIMA, Y. (1983). Construction of a Bacillus subtilis cloning vehicle with heterologous DNA sequence. Gene 24, 255-263.

Young, M. \& Mandelstam, J. (1979). Early events during bacterial endospore formation. Advances in Microbial Physiology 20, 103-162. 